\title{
Competencies of Agricultural Development Programme Personnel in Extension Service Delivery in Oyo and Ogun States Nigeria
}

https://dx.doi.org/10.4314/jae.v22i3.5

\section{Nwaogu, Fabian Kelechi}

Department of Agricultural Extension and Rural Development University of Ibadan. nwaogufabian@gmail.com, +2348038616584

\section{Akinbile, Luqman Abiodun}

Department of Agricultural Extension and Rural Development University of Ibadan. lakinbile@yahoo.com, +2348023250454

\section{Abstract}

The study assessed competencies of agricultural development programme personnel in extension service delivery in Oyo and Ogun states, Nigeria. Simple random sampling technique was used in selecting 84 extension officers from the study area of which 80 of them completed and returned their questionnaires for analysis. Data were analysed using descriptive (frequency, percentage, mean) and inferential (chi-square, PPMC, multiple regression, $t$ test) statistics. The mean age of respondents was 46 years, and the majority $(65.0 \%)$ were males, married $(95.0 \%)$, had household size of 5-6 persons (53.8\%) and had 9-16 years of job experience (40\%). All the respondents had attained tertiary education with $47.5 \%$ of them at HND level. FNT/MTRM $(\bar{x}=1.91)$ was rated the most effective education strategy while job shadowing $(\bar{x}=0.73)$ was the least effective. The majority $(57.3 \%)$ of the respondents attributed high level of importance to the selected competencies while professionalism $(\bar{x}=12.65)$ was considered the most important. Organisational management $(\bar{x}=19.70)$ was the most possessed competency, $51.2 \%$ of respondents possessed high level of competency and training need was identified in all the competency areas. The respondents level of competence was significantly related to age $(r=0.221, p \leq 0.05)$, years of work experience $(r=0.267, p \leq 0.05)$, and education strategies with short-term course/seminars (1-2 weeks) conducted at zonal level as the major predictor. Also, a significant difference existed between the competency levels of respondent in Oyo and Ogun states $(t=2.061, p \leq 0.05)$. It was recommended that the ADPs should organise special annual in-service training programmes in order to help extension officers improve their level of competence.

Keywords: Competencies, extension service delivery, ADP personnel, in-service training

\section{Introduction}

In a developing country like Nigeria, the rural people solely depend on extension officers for technical advice and information. The success of any extension programme will be determined to a large extent by the ability of her extension personnel to display competence since the whole extension delivery process is dependent on them to transfer new ideas and technical advice to the rural people (Owen, 2004). Also, the productivity of the extension organisation highly depends on the function of extension officers and as such, competent extension personnel will 
Creative commons User License: CC BY-NC-ND

Abstracted by: EBSCOhost, Electronic Journals Service (EJS), Google Scholar, Journal Seek, Scientific Commons,

Food and Agricultural Organization (FAO), CABI and Scopus
Journal of Agricultural Extension

Vol. 22 (3) October, 2018

ISSN(e): 24086851; ISSN(Print); 1119944X

http://journal.aesonnigeria.org

http://www.aiol.info/index.phpliae

Email: editorinchief@aesonnigeria.org

ensure the success of the extension service and agricultural development programmes. It is of note that the scope of agricultural extension services (AES) has been widening and the need to adapt to changing contexts is also growing.

The extension organisation is expected to achieve sustainable agricultural development and play coordinating and leadership roles among agricultural stakeholders (Rajalahti, 2012). This implies that extension organisations must understand and adjust to rapid changes and emerging challenges in order to thrive (Extension Committee on Organisational Policy, 2002). Suvedi and Ghimire (2015) noted that in recent times extension professionals are judged on how they serve their clientele; whether they show empathy and communicate effectively with their clientele, how their rapport is with their clientele and how familiar they are with their clienteles' contexts and issues. As a result of these demands, Moore (2015) opined that extension professionals should have mastery of several non-technical or process skills, such as; communication skills, critical thinking, teamwork, entrepreneurship and leadership as well as practical capacities to enable them function effectively in their service delivery.

Agricultural extension contributes to improving the welfare of farmers and other stakeholders by providing access to knowledge and information. However, Suvedi and Ghimire (2015) noted that the role of extension today goes beyond technology transfer to facilitation; beyond training to learning and includes assisting farmers to form groups, dealing with marketing issues, addressing public interest issues in rural areas such as resource conservation, health, monitoring of food security and agricultural production, food safety, nutrition, family education, youth development and partnering with a broad range of service providers and other agencies in rural development. This has led to increasing emphasis on the development of core competencies which are necessary for the extension personnel to perform at maximum and produce expected results in service delivery.

According to Issahaku (2014), Competency is a skill, a personal characteristic or a motive demonstrated by various behaviours which contributes to outstanding performance in a job. It is the quality of being adequately or well qualified, having the ability to perform a specified job. Competency assessment is designed to evaluate individual knowledge, education, skills, experience, and proficiency to perform those assigned responsibilities (Herringer, 2002). The identification of key competencies provides for individual and organisational growth, and helps the organisation meet future demands. Competencies of staff also lead to effectiveness which is a product of an organisation's ability to attain and efficiently use existing resources to achieve its goals. Therefore, focusing on competencies will aid any organisation to outline the responsibilities, knowledge, and skills required by their employees for a particular position. Because professional competencies are essential to perform jobs well, extension organisations expect their employees to use certain professional tools to help their clienteles and achieve desired results. Operationalising this concept, competencies can be referred to as an individual's knowledge, skill, abilities and behaviour which are necessary to effectively perform a specific task and achieve desirable results. It is a combination of skills, job attitude, motives, knowledge, trait 
and values which are reflected in job behaviour that can be observed, measured and evaluated.

Agricultural Extension Service in Nigeria has suffered setbacks since 1995 when the World Bank withdrew her funding of the ADPs. This has resulted to inadequate training, insufficient funding at state level, poor logistic supports, inadequate staffing, use of poorly trained personnel, and disproportionate extension agent to farm-family ratio among others. Despite the prevailing situation, it is of note that AES is a force that must be reckoned with in the process of achieving sustainable agricultural and rural development. Moreover, as a result of the Unified Agricultural Extension System (UAES), the extension officers in in the study area have a lot of responsibilities in attending to the needs of their numerous clienteles in various remote communities. An extension officer who has to assume such variety of roles amongst the farmers must prove his/her competence in many diverse areas in order to perform effectively. Also, there is dearth of information on the competency of extension officers in the study area. Therefore, it is necessary to investigate the competencies of extension personnel in Oyo and Ogun state ADPs and how these competencies can lead to better extension service delivery.

\section{Objectives of the Study}

The broad objective of the study was to assess competencies of Agricultural Development Programme personnel in Oyo and Ogun states. The specific objectives of the study were to;

1. describe the personal characteristics of the respondents;

2. identify effective education delivery methods for developing competencies of extension officers;

3. identify the level of importance of selected competencies in extension service delivery;

4. determine the level of competency possessed by respondents; and

5. examine the gap in the competencies of respondents.

\section{Hypotheses}

$\mathrm{H}_{0} 1$ : There is no significant relationship between the personal characteristics of respondents and their competency level.

$\mathrm{H}_{0} 2$ : There is no significant contribution of the education delivery methods to the competency level of extension agents.

$\mathrm{H}_{0} 3$ : There is no significant difference between the competency levels of extension officers in Oyo and Ogun state ADPs.

\section{Methodology}

The study was carried out in Oyo and Ogun state ADPs. The population of the study consisted of all the frontline extension officers working under the ADPs in the study area. Oyo and Ogun State ADPs have four agricultural zones each which include Ibadan/lbarapa, Saki, Oyo and Ogbomosho zones in Oyo state and Abeokuta, ljebu, Ikenne and Ilaro zones in Ogun state. Simple random sampling procedure was employed to select two agricultural zones from each of the states. Ibadan/lbarapa and Oyo zones were selected from Oyo state while Abeokuta and ljebu zones were selected from Ogun state. Then all the extension agents in the selected zones served 
as respondents. The decision to use $100 \%$ of the extension agents in the selected zones was due to the few number of extension officers in the zones; they includes 27 from Ibadan/lbarapa, 11 from Oyo, 28 from Abeokuta and 18 from ljebu which made up the 84 respondents interviewed during the study. Data were collected from primary source through a structured questionnaire administered to the extension officers. However, only 80 questionnaires were returned for data analysis.

\section{Measurement of Variables}

Personal Characteristics of Respondents: Age, family size and year of experience were measured at interval level while sex, marital status and educational level were measured at nominal level.

Effective Education Delivery Methods: Respondents were required to indicate their perceived level of effectiveness of selected education delivery methods in helping extension officers acquire important competencies. A 3-point scale of highly effective $(\mathrm{HE})=2$, moderately effective $(\mathrm{ME})=1$, and not effective $(\mathrm{NE})=0$ were used. The grand mean was calculated and used as a benchmark to categorise delivery methods as effective or not effective.

Competencies Considered Important in Extension Service: Thirteen competency areas were provided with 5 items under each competency area. Respondents were requested to indicate their perceived level of importance of the competencies in extension service delivery using a four-point scale of Very important $(\mathrm{VI})=3$, Important $(\mathrm{I})=2$, Slightly important $(\mathrm{SI})=1$ and Not important $(\mathrm{NI})=0$. The total score of the items under each of the 13 competency areas for each respondent was calculated and their mean computed. Then the grand mean was determined and used as a benchmark to categorise the level of importance of competencies as high or low.

Level of Competency Possessed by Respondents: Respondents were required to indicate their level of possession of each of the 13 competency areas provided on a five-point scale of Very high $(\mathrm{VH})=5$, High $(\mathrm{H})=4$, Moderate $(\mathrm{M})=3$, Low $(\mathrm{L})=2$ and very low $(\mathrm{VL})=1$. The total scores of the items under each of the competency area were calculated and their mean determined. The grand mean was computed and used to categorise the level of possession of competencies as high or low.

Competency Gap: This was determined by computing the discrepancy values (DVs). The DVs were determined on the basis of the differences between the scores of level of importance and level of possession of competencies. The scores for each respondent were first converted to percentage and then the percentage scores for level of possession were subtracted from the percentage scores for level of importance (DV = \%LI-\%LP). These differences were considered as competency gap or training needs in the identified competencies. Negative values indicate absence of training need while positive values indicate a need for training.

Data Analysis: Descriptive statistics like frequency, percentages and mean were used to describe the objectives of the study while Chi-square, PPMC, Multiple Regression analysis and T-test were used to test hypotheses of the study. 
Creative commons User License: CC BY-NC-ND

Abstracted by: EBSCOhost, Electronic Journals Service (EJS), Google Scholar, Journal Seek, Scientific Commons,

Food and Agricultural Organization (FAO), CABI and Scopus
Journal of Agricultural Extension

Vol. 22 (3) October, 2018

ISSN(e): 24086851; ISSN(Print); 1119944X

http://journal.aesonnigeria.org

http://www.ajol.info/index.php/iae

Email: editorinchief@aesonnigeria.org

\section{Results and Discussion}

\section{Personal Characteristics of Respondents}

Table 1 shows that the mean age of respondents was 46 years. Also, $32.5 \%$ of them were between 43 and 49 years and another $32.5 \%$ of them were 50 years and above. This implies that $67.5 \%$ of extension officers in the study area were less than 50 years. The result is consistent with the findings of Akinbile (2007) that population between 21 and 40 years of age constitute the active work force in Ogun state. It also means that competencies acquired through training can still be utilised for effective service delivery at the ADPs for at least 15 years. Also, the majority $(65.0 \%)$ of them were males but there were more male extension agents in Ogun state $(71.7 \%)$ than their counterparts in Oyo state (55.9\%). This agrees with the findings of Akinsorotan and Oladele (2009) that ADP extension officers were mainly males and this is not good for gender equality in extension services. The findings further reveals that the majority $(95.0 \%)$ of the respondents were married with a mean household size of 5 persons and all the respondents had attained one form of tertiary education or the other with the majority $(47.5 \%)$ of them at HND level. This corroborates with the findings of Isiaka, Lawal-Adebowale and Oyekunle (2009) that extension personnel in Lagos and Ogun states were highly educated. It implies that education, which is a means of acquiring competency for effective service delivery is a requirement for employing extension officers in the area. The mean years of working experience of extension officers was 16 years, though respondents from Ogun had more experience on the job ( $\bar{x}=19$ years) than those from Oyo $(\bar{x}=13$ years $)$. This suggests that respondents may have acquired a lot of experience on the job. However, many years of experience may not be a guarantee for competency, therefore acquiring more competencies will enable them strengthen their commitment and also function effectively in their respective service areas. 
Table 1: Personal characteristics of respondents

\begin{tabular}{|c|c|c|c|c|c|c|}
\hline \multirow[t]{2}{*}{ Variable } & \multicolumn{2}{|c|}{ Oyo } & \multicolumn{2}{|c|}{ Ogun } & \multicolumn{2}{|c|}{ Total respondents } \\
\hline & $\begin{array}{l}\text { Percentage } \\
(n=34)\end{array}$ & Mean & $\begin{array}{l}\text { Percentage } \\
(n=46)\end{array}$ & Mean & $\begin{array}{l}\text { Percentage } \\
(n=80)\end{array}$ & Mean \\
\hline \multicolumn{7}{|l|}{ Age } \\
\hline $29-35$ & 8.8 & 43.6 & 10.9 & 47.3 & 10.0 & 45.7 \\
\hline $36-42$ & 38.2 & & 15.2 & & 25.0 & \\
\hline $43-49$ & 32.4 & & 32.6 & & 32.5 & \\
\hline $50-56$ & 20.6 & & 32.6 & & 27.5 & \\
\hline $57-63$ & 0.0 & & 8.7 & & 5.0 & \\
\hline \multicolumn{7}{|l|}{ Sex } \\
\hline Male & 55.9 & & 71.7 & & 65.0 & \\
\hline \multirow{2}{*}{\multicolumn{7}{|c|}{$\begin{array}{l}\text { Memale } \\
\text { Marital status }\end{array}$}} \\
\hline & & & & & & \\
\hline Single & 5.9 & & 4.3 & & 5.0 & \\
\hline Married & 94.1 & & 95.7 & & 95.0 & \\
\hline \multicolumn{7}{|c|}{ Family size } \\
\hline $1-2$ & 5.9 & 5.4 & 8.7 & 5.0 & 7.5 & 5.2 \\
\hline $3-4$ & 17.6 & & 26.1 & & 22.5 & \\
\hline $5-6$ & 58.0 & & 50.0 & & 53.8 & \\
\hline $7-8$ & 14.7 & & 15.2 & & 15.0 & \\
\hline $9-10$ & 2.9 & & 0.0 & & 1.3 & \\
\hline \multicolumn{7}{|c|}{ Education level } \\
\hline OND & 11.8 & & 17.4 & & 15.0 & \\
\hline HND & 52.9 & & 43.5 & & 47.5 & \\
\hline B.Sc. & 26.5 & & 28.3 & & 27.5 & \\
\hline M.Sc & 8.8 & & 10.9 & & 10.0 & \\
\hline \multicolumn{7}{|c|}{ Years of experience } \\
\hline $1-8$ & 11.8 & 12.7 & 13.0 & 18.6 & 12.5 & 16.1 \\
\hline $9-16$ & 64.7 & & 21.7 & & 40.0 & \\
\hline $17-24$ & 23.5 & & 39.1 & & 32.5 & \\
\hline $25-32$ & 0.0 & & 23.9 & & 13.8 & \\
\hline $33-40$ & 0.0 & & 2.2 & & 1.3 & \\
\hline
\end{tabular}

Source: Field Survey, 2017

\section{Effective Education Delivery Method}

Table 2 shows that fortnight training (FNT)/monthly technology review meetings (MTRN) ( $\bar{x}=1.91)$ was perceived as the most effective education delivery method used by the extension agents, followed by face to face small group training workshop $(\bar{x}=1.66)$ and combination of two or more methods $(\bar{x}=1.56)$, while job shadowing $(\bar{x}=0.73)$ was the least effective. The high rating of FNT/MTRM may be due to the fact that they are the most frequently used training methods at the ADPs for effective dissemination of innovation to farmers. On the other hand, the low rating of job shadowing might be as a result of not been frequently utilised, poor information sharing and lack of motivation; during job shadowing, some professionals may find it difficult to share all the information and experiences they have gathered to the learner/observer. Furthermore, motivation is always essential towards getting success in job shadowing. If a learner is less motivated in the job they are practicing, it will have an adverse effect on the learning process as they could lose focus and miss important details regarding the job. Lakai (2010) also identified face-to-face small group workshop as the most effective education delivery method and job shadowing as the least effective in updating the competency of extension agents. The effectiveness of educational strategies utilised during training of extension agents will determine the level of competency acquisition, therefore ADPs should diversify on the use of education delivery methods by improving on the strategies used during FNT/MTRM and then adopting other effective methods to spice up the interest of the extension officers in the learning process. 
Table 2: Distribution of respondents according to effective education delivery methods

\begin{tabular}{|c|c|c|c|}
\hline Education strategies & $\begin{array}{l}\text { Oyo } \\
\text { Mean }\end{array}$ & $\begin{array}{l}\text { Ogun } \\
\text { Mean }\end{array}$ & $\begin{array}{l}\text { Total respondents } \\
\text { Mean }\end{array}$ \\
\hline FNT/MTRM & 1.97 & 1.87 & $1.91^{*}$ \\
\hline Short-term workshop (1-2 weeks) conducted at zonal level & 1.24 & 1.33 & $1.29^{*}$ \\
\hline Short term workshop (1-2 weeks) conducted at block level & 1.20 & 1.13 & $1.19^{*}$ \\
\hline $\begin{array}{l}\text { Long term workshop (above } 2 \text { weeks) conducted at zonal } \\
\text { level }\end{array}$ & 1.21 & 1.09 & 1.14 \\
\hline An individual learning through correspondence & 0.56 & 0.83 & 0.71 \\
\hline Electronic learning materials e.g. CDs & 0.71 & 0.80 & 0.76 \\
\hline Face to face small group workshops & 1.62 & 1.69 & $1.66^{*}$ \\
\hline Combination of two or more methods & 1.79 & 1.43 & $1.59^{*}$ \\
\hline Job shadowing & 0.74 & 0.72 & 0.73 \\
\hline Mentoring & 0.71 & 1.04 & 0.90 \\
\hline Grand mean & 1.18 & 1.19 & 1.19 \\
\hline
\end{tabular}

Source: Field Survey, 2017. *Effective (mean $\geq 1.19$ ).

\section{Competencies Considered Important in Extension Service Delivery}

Table 3 shows that out of the 13 competency areas, 9 were considered highly important by the respondents. Professionalism $(\bar{x}=12.65)$ was considered the most important competency followed by programme planning $(\bar{x}=12.64)$ and knowledge of organisation $(\bar{x}=12.58)$, while information communication technology $(\bar{x}=10.28)$ was considered the least important. The high importance rating of professionalism is not surprising as extension practice is anchored on it. The expectation is that a professional extension officer should demonstrate positive attitude towards extension service, have strong work ethics, effectively interpreted research findings and carry out assignments confidently without guidance. Terblanche (2007) noted that staff members who practice professionalism keep themselves abreast of current knowledge and skills. Professionalism and core competencies complement each other very well. It can thus be said that professionalism is one of the essential core competencies that extension professionals should possess to function effectively in their service delivery. The low importance rating on ICT may be due to poor awareness of ICTs and poor use of ICT tools by the respondents as a result of unavailability of these tools in their service area. Suvedi and Ghimire (2015) noted that competency of extension officers on ICT will be enhanced on the basis of how familiar they are with various and emerging ICTs and other communication tools and how effectively they use these tools in their routine work. The grand mean for each state shows that extension officers from Oyo considered the competencies more important $(\bar{x}=12.48)$ than those from Ogun $(\bar{x}=11.59)$. On the overall, $57.3 \%$ of the respondents perceived the competencies to be highly important. This implies that all the competencies identified are of high importance and necessary for effective extension service delivery and as such, should be possessed by extension officers at high level. 
Creative commons User License: CC BY-NC-ND

Abstracted by: EBSCOhost, Electronic Journals Service (EJS), Google Scholar, Journal Seek, Scientific Commons,

Food and Agricultural Organization (FAO), CABI and Scopus
Journal of Agricultural Extension

Vol. 22 (3) October, 2018

ISSN(e): 24086851; ISSN(Print); 1119944X

http://journal.aesonnigeria.org

http://www.ajol.info/index.php/iae

Email: editorinchief@aesonnigeria.org

Table 3: Level of importance of competencies

\begin{tabular}{|c|c|c|c|c|c|c|}
\hline Competency areas & \multicolumn{2}{|l|}{ Oyo } & $\begin{array}{l}\text { Ogun } \\
\text { Mean }\end{array}$ & SD & Total & SD \\
\hline Programme planning & 12.85 & 1.46 & 12.48 & 2.00 & $12.64^{*}$ & 1.79 \\
\hline Programme implementation & 12.56 & 2.58 & 12.35 & 2.04 & $12.44^{*}$ & 2.27 \\
\hline Communication skill & 12.18 & 1.75 & 11.17 & 2.03 & 11.60 & 1.97 \\
\hline Extension education and teaching & 12.50 & 1.99 & 11.76 & 2.34 & $12.08^{*}$ & 2.22 \\
\hline Information communication technology & 10.38 & 3.01 & 10.20 & 2.88 & 10.28 & 2.92 \\
\hline Leadership skill & 11.12 & 2.53 & 10.41 & 2.83 & 10.73 & 2.71 \\
\hline Social value and culture & 12.79 & 2.19 & 11.54 & 2.59 & $11.96^{*}$ & 2.52 \\
\hline Programme evaluation and research & 12.65 & 2.21 & 11.96 & 2.00 & $12.25^{\star}$ & 2.11 \\
\hline Organisational management & 13.06 & 1.70 & 12.07 & 2.39 & $12.49^{*}$ & 2.17 \\
\hline Knowledge of organisation & 13.21 & 2.13 & 12.11 & 2.52 & $12.58^{*}$ & 2.41 \\
\hline Professionalism & 13.47 & 1.26 & 12.04 & 2.15 & $12.65^{*}$ & 1.95 \\
\hline Technical subject matter expertise & 13.32 & 1.66 & 11.91 & 2.26 & $12.51^{*}$ & 2.13 \\
\hline Group management & 12.09 & 2.08 & 10.67 & 2.98 & 11.28 & 2.71 \\
\hline Grand mean & 12.48 & & 11.59 & & 11.96 & \\
\hline Overall level of possession & Percer & & Min & Max & Mean & \\
\hline Low (103-155) & 42,7 & & 103 & 186 & 156 & \\
\hline High (156-186) & 57.3 & & & & & \\
\hline
\end{tabular}

Source: Field Survey, 2017. ${ }^{*}$ High importance (mean $\geq 11.96$ ).

\section{Competencies Possessed by Extension Officers}

Table 4 reveals that the extension officers had high level of competency in seven out of the 13 competencies. Organisational management was the most possessed competency $(\bar{x}=19.70)$ followed by knowledge of organisation $(\bar{x}=19.56)$ and professionalism $(\bar{x}=18.22)$ while the least possessed competencies were information communication technology $(\bar{x}=13.64)$ and leadership $(\bar{x}=16.55)$. It was observed that most of the competencies the extension officers considered highly important were also possessed by them at high level and vice versa. It therefore means that priority should be given to those competencies they considered important during training programmes. This supports the assertion by Moore and Rudd (2005) that leadership training programs for extension officers should be based on the skills they themselves perceive to be the most important. The grand mean for each of the states reveals that the competency level of extension officers from Ogun is higher $(\bar{x}=17.62)$ than those form Oyo $(\bar{x}=17.48)$, while the overall competency level reveals that more $(51.2 \%)$ of the extension officers possessed high level of competency. This implies that competency level of the extension officers is slightly above average and therefore needs to be updated. If the advantages of possessing competencies are maximized in service delivery, it will improve the performance of extension officers. However, constant development of personal and organisational skills is paramount for frontline extension personnel because they are confronted with varying problems and emerging roles in the course of discharging their duties. 
Creative commons User License: CC BY-NC-ND

Abstracted by: EBSCOhost, Electronic Journals Service (EJS), Google Scholar, Journal Seek, Scientific Commons,

Food and Agricultural Organization (FAO), CABI and Scopus
Journal of Agricultural Extension

Vol. 22 (3) October, 2018

ISSN(e): 24086851; ISSN(Print); 1119944X

http://journal.aesonnigeria.org

http://www.ajol.info/index.php/iae

Email: editorinchief@aesonnigeria.org

Table 4: Competencies possessed by extension officers.

\begin{tabular}{|c|c|c|c|c|c|c|}
\hline Competency areas & $\begin{array}{l}\text { Oyo } \\
\text { Mean }\end{array}$ & SD & $\begin{array}{l}\text { Ogun } \\
\text { Mean }\end{array}$ & SD & $\begin{array}{l}\text { Total } \\
\text { Mean }\end{array}$ & SD \\
\hline Programme planning & 18.09 & 3.05 & 18.05 & 4.15 & $18.06^{*}$ & 3.70 \\
\hline Programme implementation & 18.09 & 3.52 & 18.11 & 3.25 & $18.10^{*}$ & 3.34 \\
\hline Communication skill & 16.59 & 3.38 & 16.88 & 3.43 & 16.74 & 3.39 \\
\hline $\begin{array}{l}\text { Extension education and } \\
\text { teaching }\end{array}$ & 16.41 & 3.10 & 17.00 & 3.57 & 16.74 & 3.37 \\
\hline $\begin{array}{l}\text { Information communication } \\
\text { technology }\end{array}$ & 13.59 & 3.60 & 13.68 & 3.86 & 13.64 & 3.73 \\
\hline Leadership skill & 16.32 & 3.39 & 16.74 & 3.57 & 16.55 & 3.48 \\
\hline Social value and culture & 18.00 & 3.06 & 18.30 & 3.17 & $18.18^{*}$ & 3.11 \\
\hline $\begin{array}{l}\text { Programme evaluation and } \\
\text { research }\end{array}$ & 17.62 & 2.46 & 17.43 & 2.78 & 17.51 & 2.63 \\
\hline Organisational management & 20.03 & 1.83 & 19.46 & 3.35 & $19.70^{*}$ & 2.81 \\
\hline Knowledge of organisation & 18.82 & 2.67 & 20.12 & 3.37 & $19.56^{*}$ & 3.14 \\
\hline Professionalism & 18.26 & 2.49 & 18.20 & 3.24 & $18.22^{*}$ & 2.93 \\
\hline $\begin{array}{l}\text { Technical subject matter } \\
\text { expertise }\end{array}$ & 18.74 & 3.56 & 17.83 & 3.30 & $18.18^{*}$ & 3.43 \\
\hline Group management & 16.62 & 2.84 & 16.87 & 3.95 & 16.76 & 3.50 \\
\hline Grand mean & 17.48 & & 17.62 & & 17.53 & \\
\hline Overall level of possession & \multicolumn{2}{|c|}{ Percentage } & Min & Max & Mean & \\
\hline $\begin{array}{l}\text { Low }(152-227) \\
\text { Hiah }(228-287)\end{array}$ & \multicolumn{2}{|l|}{$\begin{array}{l}48.8 \\
512\end{array}$} & 152 & 287 & 228 & \\
\hline
\end{tabular}

Source: Field Survey, 2017. *High possession of competency (mean $\geq 17.53$ ).

\section{Perceived Gap in Competencies}

Table 5 shows that extension officers from the two states had higher percentage of positive discrepancy values in all the 13 competencies which indicate a competency gap in the selected areas. The implication is that extension officers in the study area need training in all the competency areas. This supports the assertion by Hussain, Ali, Khan and Ahmad (2004) that there is need to continuously strengthen competencies of extension officers in developing countries in all competency areas to improve their performance in service delivery. However, the highest training need for extension officers in Oyo state was found in the areas of programme planning (91.2\%), programme implementation (88.2\%) and programme evaluation and research (88.2\%) while the highest training need in Ogun state was found in the areas of programme evaluation and research (78.3\%), programme planning (73.9\%) and communication skill $(71.7 \%)$. Updating the knowledge and skills of extension staff in the above areas is necessary and will assist them to be competent enough to face the present day challenges facing extension officers. Therefore, the training needs identified should be considered as important areas for designing future in-service training programme for the extension officers in the study area. 
Creative commons User License: CC BY-NC-ND

Abstracted by: EBSCOhost, Electronic Journals Service (EJS), Google Scholar, Journal Seek, Scientific Commons,

Food and Agricultural Organization (FAO), CABI and Scopus
Journal of Agricultural Extension

Vol. 22 (3) October, 2018

ISSN(e): 24086851; ISSN(Print); 1119944X

http://journal.aesonnigeria.org

http://www.ajol.info/index.php/iae

Email: editorinchief@aesonnigeria.org

Table 5: Discrepancies between level of importance and level of possession of competencies

\begin{tabular}{|c|c|c|c|c|}
\hline Competency areas & $\begin{array}{l}\text { Oyo } \\
\text { PDV\% }\end{array}$ & NDV \% & $\begin{array}{l}\text { Ogun } \\
\text { PDV \% }\end{array}$ & NDV \% \\
\hline Programme planning & 91.2 & 8.8 & 73.9 & 26.1 \\
\hline Programme implementation & 88.2 & 11.8 & 65.2 & 34.8 \\
\hline Communication skill & 85.3 & 14.7 & 71.7 & 28.3 \\
\hline Extension education and teaching & 79.4 & 20.6 & 60.9 & 39.1 \\
\hline Information communication technology & 76.5 & 23.5 & 67.4 & 32.6 \\
\hline Leadership skill & 73.5 & 26.5 & 56.5 & 43.5 \\
\hline Social value and culture & 77.8 & 22.2 & 54.3 & 45.7 \\
\hline Programme evaluation and research & 88.2 & 11.8 & 78.3 & 21.7 \\
\hline Organisational management & 76.5 & 23.5 & 63.0 & 37.0 \\
\hline Knowledge of organisation & 79.4 & 20.6 & 63.0 & 37.0 \\
\hline Professionalism & 76.3 & 23.7 & 67.4 & 32.6 \\
\hline Technical subject matter expertise & 79.4 & 20.6 & 69.6 & 30.4 \\
\hline Group management & 85.3 & 14.7 & 63.0 & 37.0 \\
\hline
\end{tabular}

Source: Field Survey, 2017.

Negative discrepancy values

$\mathrm{PDV}=$ Positive discrepancy values, NDV =

\section{Relationship Between Personal Characteristics of Respondents and Level of Competencies}

The result in Table 6 reveals that there was no significant relationship between sex $\left(x^{2}=2.468, p \geq 0.05\right)$, marital status $\left(x^{2}=0.951, p \geq 0.05\right)$, education level $\left(x^{2}=4.058\right.$, $p \geq 0.05)$, family size $(r=0.013, p \geq 0.05)$, and competency level of extension officers. On the other hand, there was a significant relationship between age $(r=0.221, p \leq 0.05)$, years of work experience $(r=0.267, p \leq 0.05)$ and competency level of respondents. This implies that extension agent's competency level is irrespective of sex, marital status, education level and family size but on their age and years of work experience. It therefore means that the older and more experienced an extension officers is, the higher the level of competency possessed. The implication is that extension organisations should take cognisance of level of experience when making decision to choose the best candidate for a particular assignment. Also, priority should be given to younger and less experienced extension officers when selecting staff members for in- service training. The expected relationship between education level and possession of competencies was not upheld. This may be due to the fact that extension work requires more practical experience and field exposure than the theoretical knowledge acquired through formal education. The finding is related to that of Adegoke (2015) who reported that sex, religion, marital status, educational qualification and family size were not significantly related to extension officer's knowledge of crop agricultural biotechnology in Oyo state.

Table 6: Relationship between personal characteristics and competency level

\begin{tabular}{|c|c|c|c|}
\hline Variables & $x^{2}$ & $\begin{array}{l}\text { Degree } \\
\text { freedom }\end{array}$ & of $r$ value \\
\hline Sex & 2.468 & 1 & \\
\hline Marital status & 0.951 & 1 & \\
\hline Educational level & 4.058 & 4 & \\
\hline Age & & & $0.221^{*}$ \\
\hline Family size & & & 0.013 \\
\hline $\begin{array}{l}\text { Years of } \\
\text { experience }\end{array}$ & work & & $0.267^{*}$ \\
\hline
\end{tabular}

Source: Field Survey, 2017. ${ }^{*} \mathrm{P} \leq 0.05$ 
Creative commons User License: CC BY-NC-ND

Abstracted by: EBSCOhost, Electronic Journals Service (EJS), Google Scholar, Journal Seek, Scientific Commons,

Food and Agricultural Organization (FAO), CABI and Scopus
Journal of Agricultural Extension

Vol. 22 (3) October, 2018

ISSN(e): 24086851; ISSN(Print); 1119944X

http://journal.aesonnigeria.org

http://www.ajol.info/index.php/iae

Email: editorinchief@aesonnigeria.org

\section{Relationship Between Education Delivery Methods and Competency Level}

Table 7 shows the result of multiple regression analysis conducted to examine the contribution of each of the education delivery methods on competency level of extension officers. The $\mathrm{R}^{2}$ value 0.517 obtained implies that the ten predictors explain about $51.7 \%$ of variance in the extension worker's level of competence which was revealed to be statistically significant, $F(10,69)=11.571,, p=0.003$. An inspection of individual predictors reveals that short-term courses/workshop (1-2) weeks conducted at zonal level $(\beta=0.391, p=0.000)$, FNT/MTRM $(\beta=0.236, p=0.012)$ and face to face small group training workshop $(\beta=0.213, p=0.024)$ were significant predictors of competency level of extension agents. The other predictors were found to be individually statistically insignificant in affecting the competency level of respondents. This result implies that short-term courses/workshop (1-2) weeks conducted at zonal level has the highest unique contribution to the competency of extension agents when the variance explained by all other predictors in the model is controlled.

Table 7: Relationship between education delivery methods and competency level

\begin{tabular}{|c|c|c|c|c|c|}
\hline & \multicolumn{2}{|c|}{$\begin{array}{l}\text { Unstandardized } \\
\text { Coefficients }\end{array}$} & \multirow{2}{*}{$\begin{array}{c}\text { Standardized } \\
\text { Coefficients } \\
\text { Beta }\end{array}$} & \multirow[t]{2}{*}{$t$} & \multirow[t]{2}{*}{ Sig. } \\
\hline & B & $\begin{array}{l}\text { Std. } \\
\text { Error }\end{array}$ & & & \\
\hline (Constant) & 169.989 & 21.655 & & 7.850 & .000 \\
\hline $\begin{array}{l}\text { Educational delivery } \\
\text { method...fortnight training (FNT) } \\
\text { and monthly technology review } \\
\text { meetings (MTRM) } \\
\text { short-term courses/workshop (1- } \\
\text { 2) weeks conducted at zonal level }\end{array}$ & 14.539 & 12.492 & .236 & 1.864 & .012 \\
\hline $\begin{array}{l}\text { Short term courses / Workshop } \\
\text { (1-2 weeks conducted at block } \\
\text { level }\end{array}$ & 4.345 & 5.919 & .104 & .734 & .465 \\
\hline $\begin{array}{l}\text { Long term courses / Workshop } \\
\text { (above } 2 \text { weeks) conducted at } \\
\text { zonal level }\end{array}$ & -2.988 & 5.639 & -.073 & -.530 & .598 \\
\hline $\begin{array}{l}\text { An individual style of learning } \\
\text { through correspondence courses }\end{array}$ & 9.530 & 6.336 & .188 & 1.504 & .137 \\
\hline $\begin{array}{l}\text { Electronic learning materials e.g. } \\
\text { CDs }\end{array}$ & -9.975 & 5.338 & -.223 & 1.668 & .066 \\
\hline $\begin{array}{l}\text { Face to face small group training } \\
\text { workshop }\end{array}$ & 7.834 & 6.378 & .213 & 1.728 & .024 \\
\hline $\begin{array}{l}\text { Combination of two or more } \\
\text { delivery methods }\end{array}$ & -5.431 & 6.760 & -.112 & -.803 & .425 \\
\hline Job shadowing & -1.739 & 6.337 & -.037 & -.274 & .785 \\
\hline Mentoring & 5.608 & 5.912 & .130 & .949 & .346 \\
\hline
\end{tabular}




\section{Difference in Competency Level Between Extension Officers in Oyo and Ogun state ADPs}

The result in Table 8 indicates a significant difference between the competency levels of extension officers in Oyo and Ogun states $(t=2.061$. $p \leq 0.05)$. Moreover, extension officers in Ogun state had a higher level of competency $(\bar{x}=229.06)$ than their counterparts in Oyo state $(\bar{x}=227.24)$. The reason for the higher competency level of extension officers from Ogun may be due to that fact that they had acquired more experience on the job than those from Oyo. Therefore, it could be stated that years of work experience is a determinant factor on competency level of extension officers.

Table 8: Difference between competency levels of extension agents in Oyo and Ogun states

\begin{tabular}{lllllll}
\hline Variable & & $\mathbf{N}$ & Degree of freedom & Mean & Difference & t \\
\hline Competency & Oyo & 34 & 78 & 227.24 & 1.82 & $2.061^{*}$ \\
& Ogun & 46 & & 229.06 & & \\
\hline
\end{tabular}

Source: Field Survey, 2017. ${ }^{*} \mathrm{P} \leq 0.05$.

\section{Conclusion and Recommendation}

The overall level of competence of extension officers in the study area is moderately high. Also, there is a gap between the level of importance of competencies and the level of possession of competencies and as such, there is need for training the extension officers in Oyo and Ogun state ADPs to enable them improve on their current level of competencies for effective and efficient service delivery. Hence;

the ADPs in the study area should organise annual in-service training programmes for extension officers to help them improve on their current level of competencies in all the listed areas. In a situation where the government is unable to sponsor such programmes, private donor agencies should be approached for sponsorship.

When in-service training opportunities are provided, it is important to give priority to those competencies with higher percentage of positive discrepancy values like programme planning, programme evaluation and research and communication skill; to improve the performance of extension agents in those competency areas. Also preference should be given to younger and less experienced extension officers when selecting staff that will participate in such training since they have more years to contribute to the success of the organization.

The ADPs should adopt short-term courses/workshop held at zonal level as a major training method; they should also improve on the methodology used during FNT/MTRM by diversifying on teaching methods, involving highly qualified and experienced instructors and combining two or more effective education strategies to complement each other.

\section{Reference}

Adegoke, O. A. (2015). Knowledge of crop agricultural biotechnology among agricultural extension agents in Oyo state ADP. Unpublished M.Sc project in the Department of Agricultural Extension and Rural Development, University of Ibadan.

Akinbile, L. A. (2007). Social impact of limestone exploitation in Yewa North Local Government Area of Ogun State, Nigeria. Pakistan Journal of Social Science 4(1): 107-111. 
Creative commons User License: CC BY-NC-ND

Abstracted by: EBSCOhost, Electronic Journals Service (EJS), Google Scholar, Journal Seek, Scientific Commons,

Food and Agricultural Organization (FAO), CABI and Scopus
Journal of Agricultural Extension

Vol. 22 (3) October, 2018

ISSN(e): 24086851; ISSN(Print); 1119944X

http://journal.aesonnigeria.org

http://www.ajol.info/index.php/iae

Email: editorinchief@aesonnigeria.org

Akinsorotan, A. O. and Oladele, O. I. (2009). Organisational values perceived as evident among extension agents of Agricultural Development Programme in Nigeria. Journal of Agricultural Tropical Subtropics 42(1):10-117.

Extension Committee on Organisational Policy (ECOP), (2002). The extension system: A vision for the $21^{\text {st }}$ century. Retrieved November 23, 2016 from

Http://dasnr2.dasnr.okstate.edu/documents/committee report.pdf

Herringer, J. M. (2002). Once isn't enough when measuring staff competence. Journal of Nursing Management 33(2): 22-32

Hussain, N., Ali, T., Khan, M. A. J. and Ahmad, M. (2004). Training of agricultural extension administrators in planning extension activities in Punjab, Pakistan. International Journal of Agriculture and Biology 6(5):941-942.

Issahaku, A. (2014). Perceived competencies of agricultural extension workers in extension service delivery in northern region of Ghana: Perspective from literature. Journal of Developing Country Studies 4(15):107-114.

Isiaka, B. T, Lawal-Adebowale, O. A. and Oyekunle, O. (2009). Agricultural extension agents' awareness of ICT potentials and training needs on usage for improved extension service delivery in selected southwest states of Nigeria. Journal of Humanities, Social Science and Creative Arts. 4(1):18-30

Lakai, D. (2010). Identification of Competencies needed by extension agents in North Carolina Cooperative Extension. Unpublished M.Sc Project in the Department of Extension Education, North Carolina State University.

Moore, L. L. and Rudd, R. D. (2005). Leadership skills and competencies for extension state Directors and Administrators. Journal of Agricultural Education 45(3): 22-33.

Moore, K. M. (2015). Confronting the challenges of agricultural education and Training. Paper presented at the MEAS Symposium on: Strengthening Extension and Advisory Services for Lasting Impacts Washington, D.C., pp 3-5.

Owen, M. B. (2004). Defining key sub-competencies for administrative county leaders. Journal of Extension (on-line )42(2) : 2RIB3. Retrieved March 5, 2016 from Http://www.joe.org/joe/2004april/rb3.php

Rajalahti, R. (2012). Sourcebook overview and user guide. In Agricultural innovation systems: An investment handbook. Washington D.C.: World Bank

Suvedi, M. and Ghimire, R. (2015). How competent are Agricultural Extension Agents and Extension Educators in Nepal? Retrieved November 23, 2017 from http://www.oired.vt.edu/innovate/wp

Terblanche, S. E. (2007). Towards professionalism in agricultural extension. The role of South African Society of Agricultural Extension. South African journal of agricultural Extension 36: 144-169. 